\title{
Micro-Raman spectral identification of manganese oxides black pigments in an archaeological context in Northern Chile
}

\author{
Marcela Sepúlveda ${ }^{1 \dagger}$, Sebastián Gutiérrez ${ }^{2}$, Marcelo Campos Vallette ${ }^{3 \dagger}$, Vivien G. Standen ${ }^{4}$, Bernardo T. Arriaza ${ }^{1}$ \\ and José J. Cárcamo-Vega ${ }^{2 *}$
}

\begin{abstract}
:
The micro-Raman spectroscopy was used to identify manganese oxides, pyrolusite, manganite and cryptomelane in archaeological sites in northern Atacama Desert, Chile. The present micro-Raman data allow us to compare and expand the origins of raw materials used by archaic groups of the Atacama Desert. In the Andean highlands, pyrolusite and manganite were identified while in the coastal lowlands manganite and cryptomelane were found. The present results complement the data obtained from the lithic materials and rock art painting analyses pointing to a better understanding of the daily life of ancient populations and minerals use in this region.
\end{abstract}

Keywords: Black pigment, Manganese oxides, Micro-Raman spectroscopy, Archaeological contexts, Atacama Desert

\section{Background}

Manganese ( $\mathrm{Mn})$ is one of the most abundant elements in nature-tenth within the Earth's crust [1]. Geochemically, $\mathrm{Mn}$ is part of minerals formed in the early stages of magmatic crystallization. According to Ossa [2], the genesis of manganese deposits in northern Chile was traced to the deposition by circumvolcanic hot springs during the Pleistocene, deposits of manganese occurring at modern erosion levels are due to secondary mobilization. Significant quantities of Mn persist, however, it melts and can be plentiful in late-stage deposits such as pegmatites; near the Earth's surface, $\mathrm{Mn}$ is easily oxidized, giving rise to several oxide-hydroxide minerals [1]. Its sedimentary origin can be found in simple oxides such as $\mathrm{Mn}_{\mathrm{x}} \mathrm{O}_{\mathrm{y}}$, or as mixed oxides such as $\mathrm{A}_{\mathrm{x}} \mathrm{Mn}_{\mathrm{y}} \mathrm{O}_{\mathrm{z}}$, where $\mathrm{A}$ is $\mathrm{K}$ or $\mathrm{Ba}[1$, 3 , 4]. The most common mineral is pyrolusite $\left(\mathrm{MnO}_{2}\right)$, which is black in colour [5]. Manganese is also found in other minerals [6], such as rhodochrosite $\left(\mathrm{MnCO}_{3}\right)$, rhodonite $\left(\mathrm{MnSiO}_{3}\right)$, manganite $(\mathrm{MnO}(\mathrm{OH}))$, alabandite

\footnotetext{
*Correspondence: jcarcamo@uta.cl

†Marcela Sepúlveda and Marcelo Campos Vallette contributed equally to this work

${ }^{2}$ Laboratorio de Análisis e Investigaciones Arqueométricas (LAIA),

Universidad de Tarapacá, Arica, Chile

Full list of author information is available at the end of the article
}

(MnS), cryptomelane $\left(\mathrm{K}_{\mathrm{x}}\left(\mathrm{Mn}^{4+}, \mathrm{Mn}^{3+}\right)_{8} \mathrm{O}_{16}\right)$, and hollandite $\left(\mathrm{Ba}\left(\mathrm{Mn}_{6}^{4+} \mathrm{Mn}_{2}^{3+}\right) \mathrm{O}_{16}\right)[7,8]$.

The use of manganese pigment has a long cultural history, since prehistoric time in Upper Palaeolithic [3]. Different manganese oxides in various archaeological contexts were identified by using Raman spectroscopy [9]. This technique is a recognized power tool for the analysis of archaeological objects [10-21]. It is a noninvasive and non-destructive technique, displaying high specificity, sensitivity and reproducibility [12, 22]. Raman microscopy was used in a micro-analysis of red and black colours of Palaeolithic paintings in the three limestone caves of Les Fieux, Les Merveilles and Pergouset of the Quercy District, France [20]. Results indicated the presence of hematite in the red micro-samples from each cave, goethite in a red-orange phase, amorphous carbon in some black micro-samples and Mn oxide/hydroxide in some black micro-samples. Black manganese oxides, romanechite and pyrolusite were used as pigments by prehistoric artists in the cave of Rouffignac-Saint-Cernin in Dordogne, France, from the upper Magdalenian Palaeolithic period (13,500-12,000 BP) [17].

The Atacama Desert in northern Chile is rich in different kinds of minerals that have been used to obtain pigments and produce paintings since pre-Hispanic times.

\section{Chemistry Central}


The study of manganese oxides resulted interesting since the most significant sources of manganese in northern Chile are specifically located in Andean highlands over 4800 m altitude $[2,3,23]$.

The use of manganese oxide black pigments was identified in different archaeological contexts of northern Chile from Archaic period, between 10,500 and 3700 BP (Fig. 1) [3, 24-27]. In the coastal tradition, black pigment was restricted to funerary contexts for Chinchorro hunter-gatherers and used as part of mummified bodies or as offerings, since 7000 BP [24] (Fig. 2). This colour was also described as applied to vegetable fibre and used for plant matting [3]. The minerals identified in this area were cryptomelane and hollandite [2]. In the highlands, the manganese oxide in paintings was registered only in rock art representations [28-30], mainly camelids found at different sites, more probably since the late archaic period, around 6000 BP (Fig. 2). Recently, it has been suggested that Los Pumas Mine, where the presence of cryptomelane was identified, was probably a provisioning mineral source used by the coastal tradition of Chinchorro during the archaic period. The presence of manganite was identify through micro-XRD $[3,25]$. The elementary analysis performed in some of the paintings from the highlands indicated the use of two different types of manganese compounds detected by scanning electron microscopy (SEM) and X-Ray scattering [30]. The observed difference was attributed to the presence or absence of Ba.

In this work, we perform a comparative molecular analysis of black pigments found in three archaeological sites from northern Chile. Two of them are from the highlands: Tangani (Ta-1 and Ta-14), Pampa El Muerto 3 (PM-3-aA) and one from the coast, Maderas EncoCuerpo 1 (Ari-26 and Ari-27). We also analyse samples from the Los Pumas Mine $5000 \mathrm{~m}$ above sea level, in the Andean mountains (LPM-1, LPM-2 and LPM3 ). The purpose of this comparative analysis is to give some insights about the use of manganese oxide minerals by archaic hunter-gatherers from northern Chile. The mineral characterization is mainly performed using micro-Raman Renishaw InVia Reflex apparatus. It is the intention that the present results will contribute with solid arguments to the discussion about the possible interactions between the early traditions of hunter-gatherers from the coast and the highlands in northern Chile.

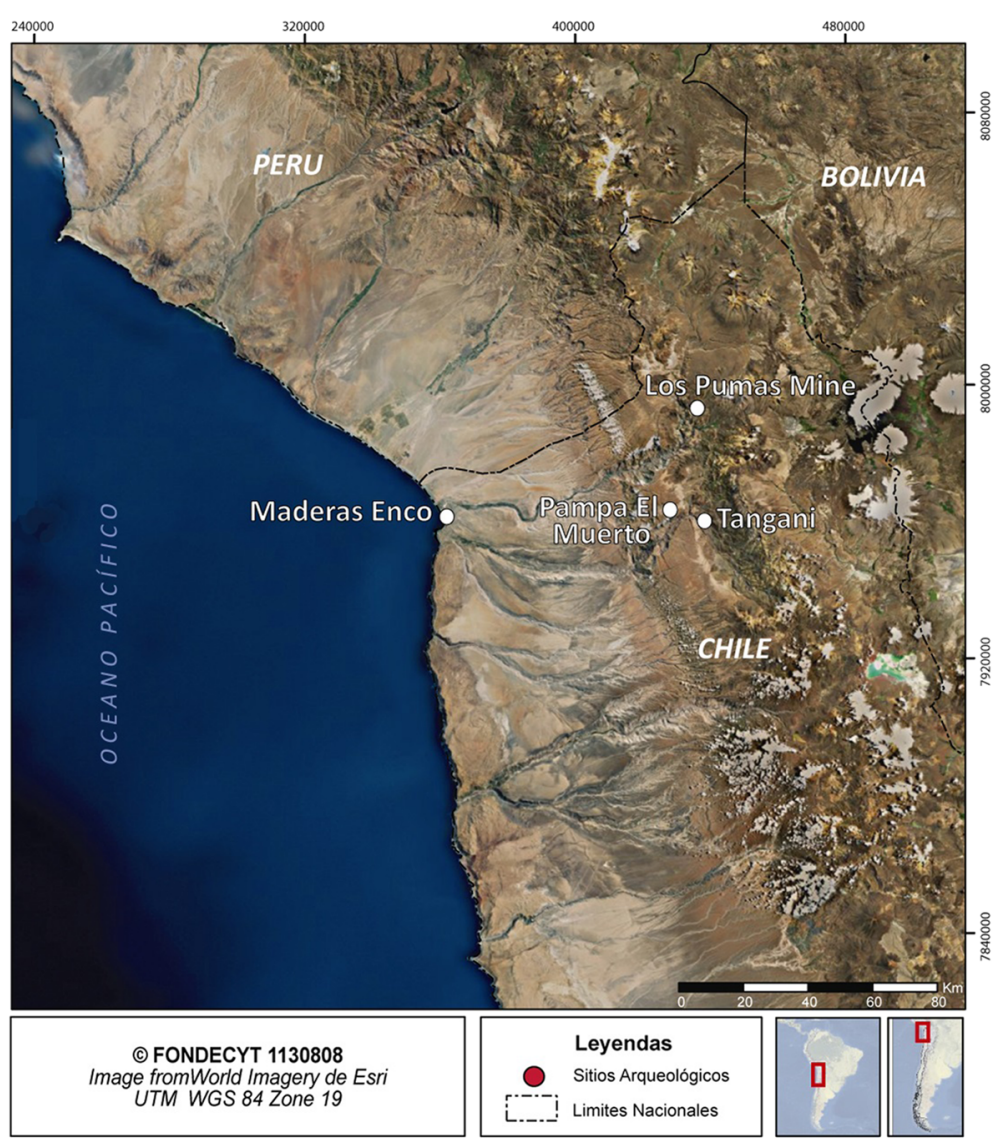

Fig. 1 Map of northern Chile. Map showing the archaeological area of archaic hunter-gatherers in Northern Chile 


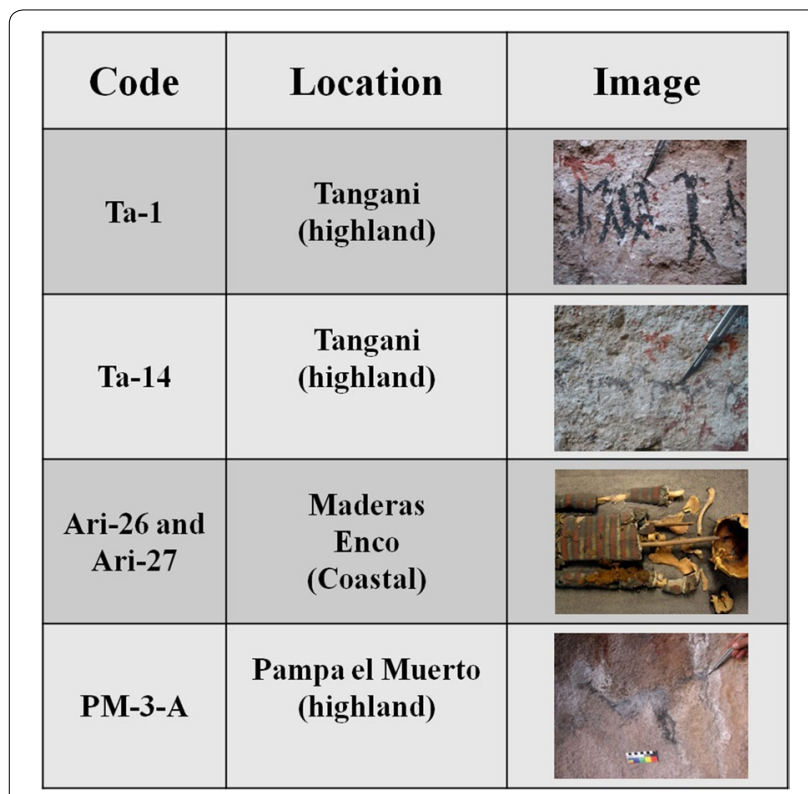

Fig. 2 Codes, localization and images of samples

\section{Methods}

\section{Samples collection}

Samples were collected in situ for rock art paintings from Tangani and Pampa El Muerto. Samples from the mummy of Maderas Enco-Cuerpo 1 were taken at the Archaeological Museum of Universidad de Tarapacá in San Miguel de Azapa (Fig. 2). In order to determine possible differences between samples, various areas of Los Pumas Mine were examined. Samples were extracted using a scalpel with a blade that was changed after each extraction. Black pigments were carefully scraped with the tip of the scalpel; grains size was in the range $2-100 \mathrm{~mm}^{2}$. Materials were gathered into a clean and sterile receptacle, preferably small glass tube, kept inside and unused.

\section{Samples description}

Ta-1. Anthropomorphic figure represented by simple black linear traces from Tangani 1. Ta-14. Anthropomorphic figure represented by simple black linear traces from Tangani 14.

PM-3-A. Black-coloured camelid figure in naturalistic style found in Pampa El Muerto 3. Ari-26 and Ari-27 are samples from the thorax of an adult individual from the Maderas Enco-Cuerpo 1 site in Arica. This mummy corresponds to one of the so-called "black mummies". The body was modelled in clay with a black surface covering it; particular alternating horizontal red and yellow stripes are observed in the trunk. Samples collected in the laboratory were classified as Ari-26 and Ari-27 [25]. This mummy is preserved at Museo Universidad de Tarapacá, San Miguel de Azapa, Arica, Chile.

LPM-1, LMP-2 and LPM-3. Samples corresponding to mineral fragments collected at the surface of different areas of Los Pumas Mine.

\section{Micro-Raman measurements}

Micro-Raman spectra of samples were recorded with a Raman Renishaw InVia Reflex apparatus, equipped with the 532, 633, and $785 \mathrm{~nm}$ laser lines, a Leica microscope and an electrically cooled CCD detector. The instrument was calibrated using the $520 \mathrm{~cm}^{-1}$ line of a Si wafer and a $50 \times$ objective. Its resolution was set to $4 \mathrm{~cm}^{-1}$ and 1-20 scans of 10-30 s each were averaged. Spectra were recorded in the $150-1800 \mathrm{~cm}^{-1}$ region. The laser power was set between 10 to $100 \mathrm{~mW}$. Spectral scanning conditions were chosen to avoid sample degradation and photodecomposition. Data was collected and plotted using the programs WIRE 3.4 and GRAMS 8.0.

\section{Results and discussion}

\section{Micro-Raman spectra of black pigments}

Micro-Raman spectra were recorded on different black zones for each sample (Figs. 3, 4). Micro-Raman spectra were assigned following published data in the RRUFF database online [8] and from Gao et al. [31]. Spectral scanning was performed in the sample areas where black

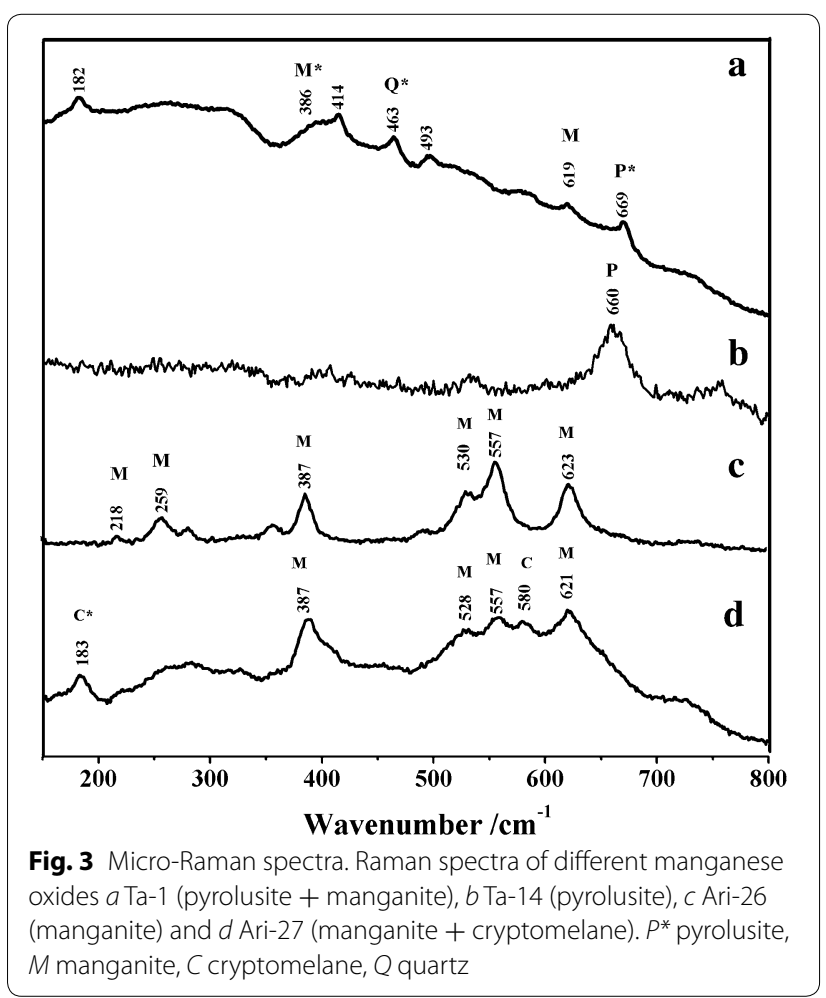




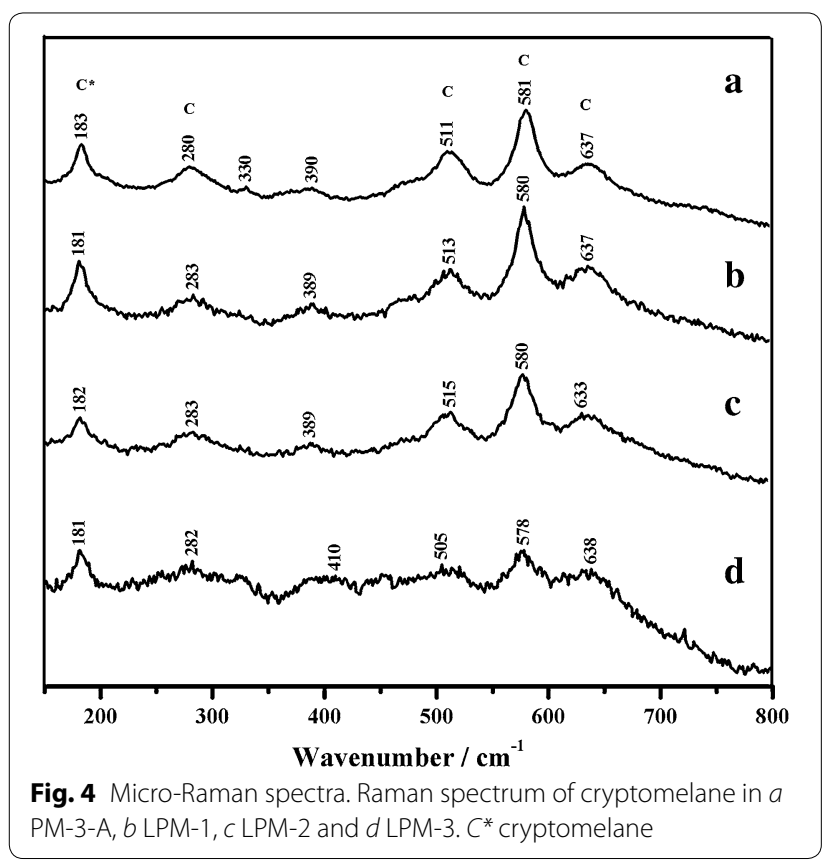

tonality was clearly identified. The spectra displayed the characteristic bands ascribed to the manganese oxide family $[8,31,32]$. The spectrum of the site Ta- 1 sample (Fig. 3a), is not easy to interpret. However, some bands were identified and assigned as a combination of manganese compounds; this is the case for the band at $669 \mathrm{~cm}^{-1}$, which was attributed to a Mn-O stretching mode $(\nu \mathrm{Mn}-\mathrm{O})$ of pyrolusite. The 386 and $619 \mathrm{~cm}^{-1}$ bands were ascribed to manganite. The band at $463 \mathrm{~cm}^{-1}$ was attributed to quartz.

The micro-Raman spectrum of the sample Ta-14 (Fig. 3b) displays a spectral profile similar to pyrolusite [8] with a unique band at $660 \mathrm{~cm}^{-1}$ ascribed to $\nu \mathrm{Mn}-\mathrm{O}$.

In the case of the sample Ari-26 (Fig. 3c), the spectrum displays the characteristic bands of manganite 218, 259, $387,530,557$ and $621 \mathrm{~cm}^{-1}[8,32,33]$. The Raman spectrum of two types of manganese oxyhydroxides, groutite and manganite, was recorded by Bernard [33]. In both cases, three bands at 388, 555 and $620 \mathrm{~cm}^{-1}$, were observed. The present spectrum is not different with the exception of the relative intensity of the last band.

The Raman bands in the spectrum of the sample Ari27 (Fig. 3d) 387, 557 and $621 \mathrm{~cm}^{-1}$ were attributed to manganite; the bands at 183 and $580 \mathrm{~cm}^{-1}$ are ascribed to cryptomelane.

Spectra in Fig. 4a-d, corresponding to samples from Pampa El Muerto (PM-3-A) and Los Pumas mine (LPM1, LPM-2 and LPM-3), show a spectral profile corresponding to cryptomelane [31]. Bands located around $183,513,580$ and $637 \mathrm{~cm}^{-1}$ were attributed to different vibrational modes of the $\mathrm{Mn}-\mathrm{O}$ moiety. The two sharp bands at 574 and $634 \mathrm{~cm}^{-1}$ would indicate a well-developed tetragonal structure with an interstitial space consisting of $(2 \times 2)$ tunnels [31]. In the present case, these bands were observed near 586 and $637 \mathrm{~cm}^{-1}$. The band at $183 \mathrm{~cm}^{-1}$ was assigned to an external vibration ascribed to a translational motion of the $\mathrm{MnO}_{6}$ octahedral, following Gao [31]. The band at $386 \mathrm{~cm}^{-1}$ was ascribed to a $\mathrm{Mn}-\mathrm{O}$ bending vibration [31]. Finally, the possibility is not excluded that hollandite was also present in the analysed samples; this is based on the strong relative intensity of the band observed at $580 \mathrm{~cm}^{-1}[8,34]$.

The molecular analysis allowed the characterization of the black pigments used by archaic communities in the lowlands and the highlands of northern Chile. From this point of view and focusing on the manganese oxides analyses, the results suggested that the sample from Ta-1 contains different manganese minerals, particularly pyrolusite and manganite. Pyrolusite was also identified in Ta-14. In Ari-26 was identified only manganite. Manganite and cryptomelane were used in Ari-27, thus confirming previous results obtained from micro-X raydiffraction [25]. Cryptomelane was also identified in the samples of PM-3-A, LPM-1, LPM-2 and LPM-3. The cryptomelane used in Pampa El Muerto as well as in Maderas Enco-Cuerpo 1 could come from high-altitude sources in the region. Coastal groups could have obtained it directly from these sources, but they also could have exchanged with highland hunter-gatherers. In the case of the manganite and pyrolusite, the mineral's origin source remains unknown, but they could come from the same source, as it is common that manganite transforms itself in pyrolusite $[35,36]$. Thus, according to these results, it is possible to infer that archaic groups used various types of raw natural manganese minerals, such as natural or intentional mixture. So it is possible to propose that inhabitants from the coastal and the highland used similar but also different minerals.

\section{Conclusions}

Manganese black minerals pyrolusite, manganite and cryptomelane in an archaeological context have been identified by micro-Raman spectroscopy. Cryptomelane was probably extracted from Los Pumas mine area. The present micro-Raman data allows comparing and expanding the origins of the raw materials used by archaic hunter-gatherers groups from the Atacama Desert. We need to identify more possible raw mineral sources. We also need to precise possible mineral modification under different conditions of preservation to understand the relation between the manganite and pyrolusite in the same samples. Finally, the present results complement the data obtained from lithic materials and rock art 
paintings, pointing to a better understanding of mineral and raw material, in general, used by ancient populations in the northern Atacama Desert.

\section{Authors' contributions}

MS: drafted the manuscript from the archaeological point of view. SG: participated in reviewing and editing of the manuscript. MCV: participated in the Raman analysis and revising of the manuscript. VGS and BTA: participated in revising the manuscript. JJCV: carried out the Raman analysis, drafted the manuscript and participated in reviewing and editing. All authors read and approved the final manuscript.

\section{Author details}

${ }^{1}$ Instituto de Alta Investigación, Universidad de Tarapacá, Arica, Chile. ${ }^{2}$ Laboratorio de Análisis e Investigaciones Arqueométricas (LAIA), Universidad de Tarapacá, Arica, Chile. ${ }^{3}$ Laboratorio de Espectroscopía Vibracional, Facultad de Ciencias, Universidad de Chile, Santiago, Chile. ${ }^{4}$ Departamento de Antropología, Universidad de Tarapacá, Arica, Chile.

\section{Acknowledgements}

This work was financially supported by Universidad de Tarapacá Proyecto UTA 3711-14 Tecnología del color durante la secuencia prehispánica del norte de Chile (Universidad De Tarapacá, Project 3711-14 Technology of Colour During the Pre-Hispanic Sequence in Northern Chile). The authors would like to thank to Convenio de Desempeño UTA-MINEDUC, and FONDECYT project 1140524

\section{Competing interests}

The authors declare that they have no competing interests.

Received: 8 January 2015 Accepted: 3 September 2015 Published online: 30 September 2015

\section{References}

1. Post JE. Manganese oxide minerals: Crystal structures and economic and environmental significance. Proc Natl Acad Sci. 1999;96:3447-54.

2. Ossa AC. Genesis of manganese deposits in northern Chile. Econ Geol. 1970;65:681-9.

3. Sepúlveda M, Valenzuela D, Cornejo L, Lienqueo H, Rousselière H. Oxidos de manganeso en el extremo norte de Chile: Abastecimiento, producción y movilidad del color negro durante el período arcaico. Chungará (Arica). 2013:45:143-59.

4. Tebo BM, Bargar JR, Clement BG, Dick GJ, Murray KJ, Parker D, Verity R, Webb SM. Biogenic manganese oxides: properties and mechanisms of formation. Annu Rev Earth Planet Sci. 2004;32:287-328.

5. Chalmin E, Menu M, Vignaud C. Analysis of rock art painting and technology of Palaeolithic painters. Meas Sci Technol. 2003;14:1590-7.

6. Kaneko T, Matsuzaki T, Kugimiya T, Ide K, Kumakura M, Kasama A. Improvement of Mn Yield in less slag blowing at BOF by use of sintered manganese ore. J Iron Steel Inst Jpn Jpn Edn. 1993;79:941-7.

7. Najafpour MM. Hollandite as a functional and structural model for the biological water oxidizing complex: manganese-calcium oxide minerals as a possible evolutionary origin for the $\mathrm{CaMn}_{4}$ cluster of the biological water oxidizing complex. Geomicrobiol J. 2011;28:714-8.

8. Downs R. The RRUFF Project: an integrated study of the chemistry, crystallography, Raman and infrared spectroscopy of minerals. In: Program and abstracts of the 19th general meeting of the international mineralogical association in Kobe, Japan. 003-13, 2006

9. Clark RJH, Curri L, Henshaw GS, Laganara C. Characterization of brownblack and blue pigments in glazed pottery fragments from Castel Fiorentino (Foggia, Italy) by Raman microscopy, X-ray powder diffractometry and X-ray photoelectron spectroscopy. J Raman Spectrosc. 1997;28:105-9.

10. Aguayo T, Clavijo E, Eisner F, Ossa-Izquierdo C, Campos-Vallette MM Raman spectroscopy in the diagnosis of the wall painting History of Concepción, Chile. J Raman Spectrosc. 2011;42:2143-8.

11. Andrikopoulos KS, Daniilia S, Roussel B, Janssens K. In vitro validation of a mobile Raman-XRF micro-analytical instrument's capabilities on the diagnosis of Byzantine icons. J Raman Spectrosc. 2006:37:1026-34.
12. Bellot-Gurlet L, Pagès-Camagna S, Coupry C. Raman spectroscopy in art and archaeology. J Raman Spectrosc. 2006;37:962-5.

13. Bersani D, Lottici PP, Vignali F, Zanichelli G. A study of medieval illuminated manuscripts by means of portable Raman equipments. J Raman Spectrosc. 2006;37:1012-8.

14. Burgio L, Clark RJH, Muralha VSF, Stanley T. Pigment analysis by Raman microscopy of the non-figurative illumination in 16th- to 18th-century Islamic manuscripts. J Raman Spectrosc. 2008;39:1482-93.

15. Casanova-González E, García-Bucio A, Ruvalcaba-Sil JL, Santos-Vasquez V, Esquivel B, Falcón T, Arroyo E, Zetina S, Roldán ML, Domingo C. Surfaceenhanced Raman spectroscopy spectra of Mexican dyestuffs. J Raman Spectrosc. 2012;43:1551-9.

16. De Santis A, Mattei E, Pelosi C. Micro-Raman and stratigraphic studies of the paintings on the 'Cembalo' model musical instrument (A.D. 1650) and laser-induced degradation of the detected pigments. J Raman Spectrosc. 2007;38:1368-78.

17. Lahlil S, Lebon M, Beck L, Rousselière H, Vignaud C, Reiche I, Menu M, Paillet P, Plassard F. The first in situ micro-Raman spectroscopic analysis of prehistoric cave art of Rouffignac St-Cernin, France. J Raman Spectrosc. 2012:43:1637-43.

18. David RA, Edwards HGM, Farwell DW, De Faria DLA. Raman spectroscopic analysis of ancient Egyptian pigments. Archaeometry. 2001;43:461-73.

19. Sepúlveda M, Gutierrez S, Campos-Vallette M, Clavijo E, Walter P, Carcamo $J$. Raman spectroscopy and X-ray fluorescence in molecular analysis of yellow blocks from the archeological site Playa Miller 7 (northern Chile). J Chil Chem Soc. 2013;58:1836-9.

20. Smith DC, Bouchard M, Lorblanchet M. An initial Raman microscopic investigation of prehistoric rock art in caves of the Quercy District, S.W. France. J Raman Spectrosc. 1999;30:347-54.

21. Vandenabeele P, Edwards HGM, Moens L. A decade of Raman spectroscopy in art and archaeology. Chem Rev. 2007;107:675-86

22. Smith GD, Clark RJH. Raman microscopy in archaeological science. J Archaeol Sci. 2004;31:1137-60.

23. García M, Clavero JG, Hérail G. Carta geológica de Chile. Serie geología básica n 84. Hoja Arica-Región de Tarapacá. escala 1: 250.000. In: Subdirección Nacional de Geología, Servicio Nacional de Geología y Minería, Santiago de Chile, 2004

24. Standen VG, Santoro CM. Patrón funerario arcaico temprano del sitio Acha-3 y su relación con Chinchorro: Cazadores, pescadores y recolectores de la costa norte de Chile. Latin Am Antiq. 2004:15:89-109.

25. Sepúlveda M, Rousseliere H, Van Elslande E, Arriaza B, Standen V, Santoro CM, Walter P. Study of color pigments associated to archaic chinchorro mummies and grave goods in Northern Chile (7000-3500 BP). Herit Sci. 2014:2(7):1-12.

26. Arriaza B, Rivera MA, Schiappacasse V, Wise K. Tipología de las momias Chinchorro y evolución de las prácticas de momificación. Chungara. 1994;26:11-47.

27. Muñoz I, Chacama J, Arriaza B, Aufderheide A. Patrón de asentamiento y cronología de Acha-2. In: Muñoz I, Arriaza BT, Aufderheide AC, editors. Acha-2 y los orígenes del poblamiento humano en Arica. Arica: Universidad de Tarapacá; 1993. p. 21-46.

28. Santoro CM. Antiguos cazadores de la puna (9000-6000 AC). In: Hidalgo J, Schiappacasse HNV, Aldunate C, Solimano I, editors. Prehistoria, desde sus Orígenes hasta los Albores de la Conquista. Santiago: Editorial Andrés Bello; 1989. p. 33-55.

29. Sepúlveda M, García M, Calás E, Carrasco C, Santoro C. Pinturas rupestres y contextos arqueológicos de la precordillera de Arica (extremo norte de Chile). Estudios atacameños. 2013:46:27-46.

30. Sepulveda M, Laval E, Cornejo L, Acarapi J. Elemental characterisation of pre-hispanic rock art and arsenic in northern Chile Rock Art Research. J Austr Rock Art Res Assoc (AURA). 2012;29:93-107.

31. Gao T, Glerup M, Krumeich F, Nesper R, Fjellvåg H, Norby P. Microstructures and spectroscopic properties of cryptomelane-type manganese dioxide nanofibers. J Phys Chem C. 2008;112:13134-40.

32. Buzgar N, Apopei Al, Buzata A. Romanian database of Raman spectroscopy. 2009. http://rdrs.uaic.ro.

33. Bernard M-C, Hugo-Le Goff A, Thi BV, de Torresi SC. Electrochromic reactions in manganese oxides I. Raman analysis. J Electrochem Soc 1993:140:3065-70. 
34. Julien CM, Massot M, Poinsignon C. Lattice vibrations of manganese oxides: part I. Periodic structures. Spectrochim Acta Part A Mol Biomol Spectrosc. 2004;60:689-700.

35. Champness PE. The transformation manganite $\rightarrow$ pyrolusite. Mineral Mag. 1971;38:245-8.
36. Busncx PR. Topotactic relations among pyrolusite, manganite, and $\mathrm{Mn}_{5} \mathrm{O}_{8}$ : a high-resolution transmission electron microscopy investigation. Am Mineral. 1986;71:805-14.
Publish with ChemistryCentral and every scientist can read your work free of charge

"Open access provides opportunities to our colleagues in other parts of the globe, by allowing anyone to view the content free of charge."

W. Jeffery Hurst, The Hershey Company.

- available free of charge to the entire scientific community

- peer reviewed and published immediately upon acceptance

- cited in PubMed and archived on PubMed Central

- yours - you keep the copyright

Submit your manuscript here:

http://www.chemistrycentral.com/manuscript/ 